\title{
Chemical Composition and Rheological Parametrs of Helianthus Tuberosus Flour Used as a Sources of Bioactive Compounds in Bakery
}

\author{
LIVIA APOSTOL ${ }^{1}$, NASTASIA BELC ${ }^{1 *}$, LIVIU GACEU2*, VALENTIN VLADUT ${ }^{3}$, OANA BIANCA OPREA ${ }^{2}$ \\ ${ }^{1}$ National Research \& Development Institute for Food Bioresources - IBA Bucharest, 6 Dinu Vintila Str., 0211202, Bucharest, \\ Romania \\ ${ }^{2}$ Transilvania University of Brasov, 29 Eroilor Blvd., 500036, Brasov, Romania \\ ${ }^{3}$ National Research and Development Institute for Machines and Installations Designed to Agriculture and Food Industry - \\ INMA Bucharest, 6 Ion Ionescu de la Brad, 013813, Bucharest, Romania
}

\begin{abstract}
The main aim of this study was to establish the optimum dose of Jerusalem artichoke (Helianthus tuberosus L.) flour to be used as a functional ingredient in the bakery products industry, from both a nutritional and technological point of view. $H$. tuberosus has an important functional potential given by its high content of inulin, minerals, amino acids, and organic silicon. In this work, H. tuberosus flour was used for the enrichment of wheat flour with functional biocompounds. The experiments evaluated the functional potential of wheat flour enriched with $\mathrm{H}$. tuberosus flour, in different proportions, by examining the chemical composition and rheological behaviour of the doughs. It was found that incorporation up to a $5 \%$ into the formulation of wheat flour yielded an acceptable product in terms of rheological parameters, with improved nutritional and functional properties.
\end{abstract}

Keywords: bakery functional ingredient, inulin, mineral

Known for over 2000 years, Jerusalem artichoke (Helianthus tuberosus L.) from the Asteraceae family is a perennial plant found in the Northeast of USA. It is cultivated in temperate areas for its edible tuber. As a source of inulin, which has aperient, cholagogue, diuretic, spermatogenic, stomachic and tonic effects, its tuber has been used as a traditional remedy in the treatment of diabetes and rheumatism [1].

More recently, research done by multiple teams has proven that the chemical composition of $H$. tuberosus has a positive influence on gastrointestinal system mechanisms, as the plant contains a high concentration of minerals [2-4] and inulin [5, 7, 8].

Literature surveys reveal a massive consumer interest in bakery products enriched with functional ingredients; thus, technological developments have been made towards developing more products of this kind [9]. Many research studies have been carried out, with the purpose to improve the nutritional values and functional properties of wheat flour that involved the addition of numerous other ingredients, such as dietary fibre from coconut flour [10], mango peels as an antioxidant source $[9,11]$, soy protein [12], apple pomace [13], olives, onion, garlic [14], potato peel [15] and guar gum [16]. In addition, Bajiæ et al. [17] have used plant extracts (rosemary, thyme, sage) in the production of bakery products. Inulin mixed with water creates a gel network, which gives a smooth and creamy texture [18-19]. The aim of this study shows how $H$. tuberosusalso can be utilized to increase the dietary fibre and mineral content of wheat flour.

\section{Experimental part \\ Materials and methods}

Jerusalem artichoke (Helianthus tuberosusL.) tuberflour was supplied by SC Hofigal Export Import SA, (Bucharest, Romania) and obtained by finely grinding the tubers. The wheat flour used in the study was type 550 (0.55\% dry matter (DM) ash content) and was provided by Titan SA (Bucharest, Romania).

Preparation of flour mixtures. As shown in table 1, four samples of mixtures of wheat flour (type 550) with different proportions of $H$. tuberosus tuber flour were prepared by mixing in the following ratios: 95:5, 90:10, 85:15 and 80:20 (w/w). P1 is $100 \%$ wheat flour and P6 is $100 \% \mathrm{H}$. tuberosus tuber flour.

\section{Chemical analysis}

Moisture was determined at $103^{\circ} \mathrm{C}\left( \pm 2^{\circ} \mathrm{C}\right)$ using test samples weighing $2 \mathrm{~g}$, until constant weight was achieved between measurements, as described in the ICC Standard No. 110/1. The ash content was determined by incineration at $525 \pm 25^{\circ} \mathrm{C}$ (ICC No. 104/1). Total fat was determined by extracting $10 \mathrm{~g}$ of sample with petroleum ether $40-65^{\circ} \mathrm{C}$, using a semiautomatic Soxhlet Foss Extraction System 2055 (Foss, Sweden). Total nitrogen (N) and crude protein content ( $\mathrm{N}$ 6.50, conversion factor) was estimated using the Macro Kjeldahl method (Kjeltec System, FOSS, Sweden). Total fibre was measured using the enzymatic gravimetric method, Mes-Tris buffer, AOAC (1995) method 991.43. The determination was performed using the Fibertec 1023 system (FOSS Sweden). Each sample was analysed in triplicate.

\begin{tabular}{|l|l|}
\hline P1 & $100 \%$ wheat flour (type 550 ) \\
\hline P2 & $95 \%$ wheat flour (type 550$)+5 \%$ H. tuberosus tuber flour \\
\hline P3 & $90 \%$ wheat flour (type 550$)+10 \%$ H. tuberosus tuber flour \\
\hline P4 & $85 \%$ wheat flour (type 550$)+15 \%$ H. tuberosus tuber flour \\
\hline P5 & $80 \%$ wheat flour (type 550 ) $+20 \%$ H. tuberosus tuber flour \\
\hline P6 & $100 \%$ H. tuberosus tuber flour \\
\hline
\end{tabular}

Table 1

TYPES OF FLOURS USED IN THE EXPERIMENTS 
Inulin analysis

Inulin was determined according to the Determination of inulin in dough products method, Petkovaet al. [20]: the inulin extraction from the samples was carried out in an Ultrawave ultrasonic bath operating at a $60 \mathrm{~Hz}$ ultrasonic frequency and at $240 \mathrm{~V}$. Then the samples were centrifuged in an Eppendorf 5804R centrifuge. The spectrophotometric determination of fructans was carried out by the resorcinol assay. The absorbance of pink colored compound was read at $480 \mathrm{~nm}$ against distilled water.

The concentration of inulin in the sample extracts was calculated using the calibration curve of fructose [20-21]. Measurements were performed using a Jasco V 550 UVVis spectrophotometer.

The content of inulin was calculated by the method described in [20], using the formula:

$Y=0.1174 X+0.0087$; where: $Y$ is absorbance at 480 $\mathrm{nm} ; X$ - concentration of fructose, $\mu \mathrm{g} \mathrm{mL}^{-1}$.

\section{Mineral analysis}

The mineral contents were determined using the plasma-mass spectrometer ICP-MS (Perkin Elmer NexION 300Q). Total ash was determined by incineration of the samples at $550^{\circ} \mathrm{C}$, in an oven. Analysis was performed using an external standard (Merck, multi element standard solution) and all calibration curves were obtained for six different concentrations. The total mineral content was measured using their most abundant isotopes. The dried samples were digested in a mixture of concentrated $\mathrm{HCl}$. All measurements were made in triplicate.

\section{Testing of rheological properties of doughs}

The rheological behaviour of doughs was analysed using the predefined Chopin + protocol on Mixolab (www.chopin.fr), a piece of equipment created by CHOPIN Technologies, which uses the international standard ICCStandard Method No. 173 protocol for a complete characterization of flours.

The procedure parameters used for the analysis with Mixolab are as follows: tank temperature $30^{\circ} \mathrm{C}$, mixing speed $80 \mathrm{~min}^{-1}$, heating rate $2^{\circ} \mathrm{Cmin}{ }^{-1}$, total analysis time $45 \mathrm{~min}$.
The Mixolab curves are characterised by their torque in five defined points $(C 1-C 5, N \cdot m)$, as described in table 2 , their temperatures and corresponding processing time. Mixolab tests the correlation between the parameters in table 3 during the mixing and heating of the dough [22].

\section{Dough preparation and baking procedure}

The bread formula is made from wheatflour, dried yeast $(3.0 \mathrm{~g})$, sodium chloride $(1.5 \mathrm{~g}), H$. tuberosus tuber flour, and water according to the Mixolab water absorption. Samples were coded according to table 1.

The mixtures of flours were sieved twice (sieve Nos. 70 and $212 \mathrm{~mm}$ ). All ingredients were added into a mixer (Diosna, Germany). The program consisted of a kneading step of $10 \mathrm{~min}$, then resting for $5 \mathrm{~min}$ prior to rounding and fermentation for $30 \mathrm{~min}$ at $28-30^{\circ} \mathrm{C}$. Two dough pieces of $600 \mathrm{~g}$ were formed by re-shaping, placed in tins and then fermented at $30^{\circ} \mathrm{C}$, RH $90 \%, 60 \mathrm{~min}$. The fermented samples were baked at $200 \pm 5^{\circ} \mathrm{C}$ in a baking oven (Mondial Forni-Verona). After baking, the bread was cooled down at room temperature for $2 \mathrm{~h}$ before measurements.

\section{Specific volume measurement}

Data is reported as the mean of three measurements, each loaf was weighed and its volume was determined by the rapeseed displacement method (AACC, 2000).

\section{Porosity measurement}

Porosity was determined by measuring the total volume of the holes in a known volume of crumb while mass and density are known. Porosity is expressed in \% volume.

Elasticity was measured by applying a pressing force on a piece of bread crumb to bring it to half of its initial height and then removing the pressing force, and measuring the height recovery of the test sample one minute after removal of the load. Crumb elasticity is the ratio between the height expressed in \% by pressing and return, and the initial height of the bread crumb.

\section{Determination of sensory characteristics}

The bread score is determined based on the quantification of a set of sensory characteristics, reported

Table 2

THE PARAMETERS USED TO EVALUATE MIXOLAB CURVES

\begin{tabular}{|c|c|c|c|}
\hline Point & Significance & \multicolumn{2}{|c|}{ Associated parameters } \\
\hline $\mathrm{C} 1$ & Used to calculate water absorption & $\mathrm{T}^{\circ} \mathrm{C} 1$ and $\mathrm{T} 1$ & \multirow{5}{*}{$\begin{array}{c}\text { Dough temperature and } \\
\text { the time required for } \\
\text { different types of torque } \\
\text { to appear }\end{array}$} \\
\hline $\mathrm{C} 2$ & $\begin{array}{l}\text { Measures protein weakening as a function of mechanical work } \\
\text { and temperature }\end{array}$ & $\mathrm{T}^{\circ} \mathrm{C} 2$ and $\mathrm{T} 2$ & \\
\hline $\mathrm{C} 3$ & Measures starch gelatinization & $\mathrm{T}^{\circ} \mathrm{C} 3$ and $\mathrm{T} 3$ & \\
\hline $\mathrm{C} 4$ & Measures the stability of the hot-formed gel & $\mathrm{T}^{\circ} \mathrm{C} 4$ and $\mathrm{T} 4$ & \\
\hline $\mathrm{C} 5$ & Starch retrogradation during the cooling period & $\mathrm{T}^{\circ} \mathrm{C} 5$ and $\mathrm{T} 5$ & \\
\hline
\end{tabular}

Table 3

MIXOLAB PARAMETERS

\begin{tabular}{|c|c|c|}
\hline Parameter & Calculation method & Significance \\
\hline $\begin{array}{c}\text { Water absorption } \\
(\%)\end{array}$ & $\begin{array}{l}\text { Quantity of water required to obtain } \mathrm{C} 1= \\
\qquad 1.1 \mathrm{Nm}+1-0.05\end{array}$ & $\begin{array}{l}\text { Quantity of water the flour can absorb to achieve a given } \\
\text { consistency during the constant temperature phase }\end{array}$ \\
\hline Time for $\mathrm{C} 1(\mathrm{~min})$ & Time required to obtain $\mathrm{C} 1$ & $\begin{array}{l}\text { Dough formation time: the stronger the flour, the longer } \\
\text { it takes }\end{array}$ \\
\hline Stability (min) & $\begin{array}{c}\text { Time during which torque is }>\mathrm{C} 1-11 \% \\
\text { (constant } \mathrm{T}^{\circ} \text { phase) }\end{array}$ & $\begin{array}{l}\text { Dough resistance to kneading: The longer it takes the } \\
\text { "stronger" the dough }\end{array}$ \\
\hline Amplitude $(\mathrm{N} \bullet \mathrm{m})$ & Curve width at $\mathrm{C} 1$ & $\begin{array}{l}\text { Dough elasticity: the higher the value, the greater the } \\
\text { flour elasticity }\end{array}$ \\
\hline
\end{tabular}


to a standard volume of $400 \mathrm{~cm}^{3} 100 \mathrm{~g}^{-1}$ and $85 \%$ porosity, validated by Institute for Food Bioresources, Bucharest.

\section{Moisture content measurement}

Moisture content was determined by drying the bread crumb at $103^{\circ} \mathrm{C}\left( \pm 2^{\circ} \mathrm{C}\right)$ to constant weight. For determination, approximately $5 \mathrm{~g}$ of crumb was taken from central slice of the loaf. Data are reported as the mean of three measurements, each one performed on a freshly made loaf. In table 4, is presented a summary of organoleptic evaluation scores.

\section{Acidity measurement}

Acidity, expressed in degrees (SR 91/2007), was determined by titration of an aqueous extract of bread with $0.1 \mathrm{~N} \mathrm{NaOH}$ solution, in the presence of phenolphthalein as indicator.

Table 4

ORGANOLEPTIC EVALUATION SCORES

\begin{tabular}{|c|l|}
\hline Indicator & Scores \\
\hline Volume & 24 \\
\hline Marginal crack height & 7 \\
\hline Crust colour & 7 \\
\hline Crumb appearance & 10 \\
\hline Porosity & 20 \\
\hline Elasticity & 20 \\
\hline Aroma & 12 \\
\hline Total & 100 \\
\hline
\end{tabular}

COMPONENTS OF WHEAT FLOUR, Table 5

\begin{tabular}{|c|c|c|c|c|c|c|}
\hline $\begin{array}{c}\text { Composition } \\
\% \text { dry matter (DM) }\end{array}$ & P1 & $\mathrm{P} 2$ & P3 & P4 & P5 & P6 \\
\hline Protein content & $13.66 \pm 0.24$ & $13.48 \pm 0.26$ & $13.31 \pm 0.25$ & $13.15 \pm 0.20$ & $13.00 \pm 0.21$ & $10.45 \pm 0.21$ \\
\hline Ash content & $0.55 \pm 0.01$ & $0.79 \pm 0.02$ & $1.03 \pm 0.03$ & $1.29 \pm 0.04$ & $1.54 \pm 0.05$ & $5.6 \pm 0.10$ \\
\hline Lipids content & $1.11 \pm 0.06$ & $1.06 \pm 0.06$ & $1.05 \pm 0.08$ & $1.03 \pm 0.07$ & $1.01 \pm 0.07$ & $0.75 \pm 0.06$ \\
\hline Total sugar content & $2.00 \pm 0.05$ & $2.03 \pm 0.06$ & $2.12 \pm 0.06$ & $2.21 \pm 0.06$ & $2.30 \pm 0.05$ & $3.62 \pm 0.09$ \\
\hline Total fibre content & $1.8 \pm 0.13$ & $5.6 \pm 0.40$ & $13.35 \pm 0.83$ & $16.01 \pm 0.77$ & $17.02 \pm 0.88$ & $79.46 \pm 1.19$ \\
\hline Inulin content & 0 & $3.12 \pm 0.27$ & $6.15 \pm 0.45$ & $9.40 \pm 0.30$ & $12.35 \pm 0.63$ & $63.01 \pm 1.02$ \\
\hline
\end{tabular}

Explanations of types of flours in table 1

Table 6

MINERAL CONTENTS OF WHEAT FLOUR, TUBER FLOUR AND THEIR MIXTURES

\begin{tabular}{|c|c|c|c|c|c|c|}
\hline $\begin{array}{c}\text { Mineral } \\
\text { content,mg100 } \\
\mathrm{g}^{-1}\end{array}$ & P1 & P2 & P3 & P4 & P5 & P6 \\
\hline $\mathrm{Ca}$ & $43.81 \pm 0.68$ & $49.92 \pm 0.99$ & $56.08 \pm 1.02$ & $62.22 \pm 1.01$ & $68.36 \pm 1.05$ & $166.77 \pm 0.95$ \\
\hline $\mathrm{Mg}$ & $47.70 \pm 1.05$ & $50.07 \pm 1.11$ & $52.30 \pm 1.15$ & $54.51 \pm 1.15$ & $56.70 \pm 1.11$ & $92.15 \pm 1.34$ \\
\hline $\mathrm{Na}$ & $30.60 \pm 0.29$ & $31.35 \pm 0.29$ & $32.11 \pm 0.30$ & $32.89 \pm 0.30$ & $33.67 \pm 0.29$ & $46.23 \pm 0.29$ \\
\hline $\mathrm{K}$ & $187.80 \pm 0.34$ & $321.85 \pm 0.34$ & $457.56 \pm 0.34$ & $592.68 \pm 0.33$ & $727.69 \pm 0.34$ & $2889 \pm 0.32$ \\
\hline $\mathrm{Cu}$ & $0.77 \pm 0.01$ & $0.78 \pm 0.01$ & $0.78 \pm 0.02$ & $0.81 \pm 0.01$ & $0.81 \pm 0.01$ & $0.96 \pm 0.01$ \\
\hline
\end{tabular}

Explanations of types of flours in table 1

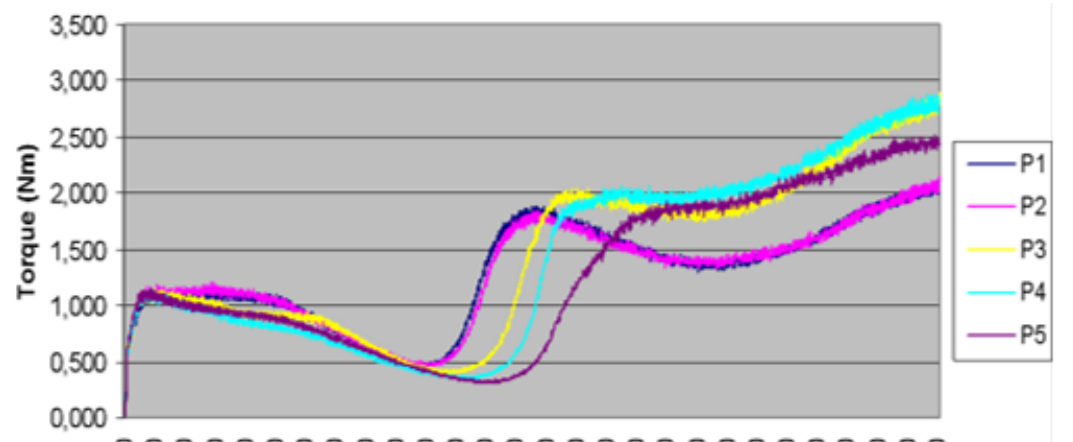

Fig.1. Mixolab torque curves $(\mathrm{N} \cdot \mathrm{m})$ of wheat and wheat-tubers composite flours

\section{Statistical analysis}

All analyses were performed in triplicate and the mean values with the standard deviations were reported. crosoft Excel 2007 was employed for statistical analysis An level of significance set at 95\%. Differences were considered significant for a value of $P<$ 0.05 .

\section{Chem and discussions}

Chemical analysis of flour mixtures. H. tuberosus tuber insoluble) (table 5). These data confirm that $H$. tuberosus tuber flour is a good source of nutrients, especially inulin, which is the major component ( $63.01 \% \mathrm{DM})$ of total fibres (79.46\% DM). calcium $(0.29 \%)$, and magnesium (0.6\%) (table 6). It can be noticed that compared to the low mineral content of wheat flour (P1), mixtures of wheat flour and $H$. tuberosus tuber flour have higher contents of minerals as the increases. Analysis of variance (ANOVA) followed by Tukey's test was

Table 5 
Table 7

INFLUENCE ON MIXOLAB CHARACTERISTICS OF H. TUBEROSUS FLOUR ADDITION

\begin{tabular}{|c|c|c|c|c|c|c|}
\hline Parameter & Abbreviation & P1 & $\mathrm{P} 2$ & P3 & P4 & P5 \\
\hline Water absorption $\%$ & $\mathrm{CH}$ & 61 & 59 & 54 & 50.6 & 46.8 \\
\hline Stability min & ST & 8.97 & 8.53 & 5.48 & 5.05 & 4.28 \\
\hline \multicolumn{7}{|c|}{ Maximum consistency during: } \\
\hline \multirow[t]{2}{*}{ phase $1(\mathrm{~N} \cdot \mathrm{m})$} & $\mathrm{C} 1$ & 1.11 & 1.14 & 1.09 & 1.08 & 1.1 \\
\hline & TC1 & 4.68 & 3.84 & 1.78 & 1.68 & 1.4 \\
\hline \multirow{2}{*}{ phase $2(\mathrm{~N} \cdot \mathrm{m})$} & $\mathrm{C} 2$ & 0.47 & 0.45 & 0.4 & 0.35 & 0.32 \\
\hline & $\mathrm{TC} 2$ & 16.27 & 16.8 & 17.6 & 18.6 & 20 \\
\hline \multirow{2}{*}{ phase $3(\mathrm{~N} \cdot \mathrm{m})$} & $\mathrm{C} 3$ & 1.79 & 1.83 & 1.98 & 1.99 & 0.53 \\
\hline & TC3 & 22.72 & 23.02 & 25.27 & 27.73 & 23 \\
\hline \multirow{2}{*}{ phase $4(\mathrm{~N} \cdot \mathrm{m})$} & $\mathrm{C} 4$ & 1.35 & 1.38 & 1.8 & 1.94 & 1.85 \\
\hline & TC4 & 33 & 32.05 & 31.8 & 30.03 & 30 \\
\hline \multirow{2}{*}{ phase $5(\mathrm{~N} \cdot \mathrm{m})$} & $\mathrm{C5}$ & 2.05 & 2.07 & 2.45 & 2.77 & 2.8 \\
\hline & TC5 & 45 & 45 & 45 & 45 & 45 \\
\hline
\end{tabular}

Explanations of types of flours in Table 1; explanations of TC1-TC5; C1-C5 in Table 2; CH - water absorption \%; ST - stability time, $\min$

Rheological properties of doughs mixtures

The rheological behaviours of wheat flour dough (P1) and of all four mixtures during the Mixolab testare illustrated in figure 1 and table 7.

Mixolab C1-C5 values of pure wheat dough (P1) were $1.10,0.47,1.79,1.35$ and $2.05 \mathrm{~N} \cdot \mathrm{m}$, respectively. Similar behaviour was mentioned by Papouskova et al. [23] for three wheat varieties, with only small differences (C1-C5 averages $1.12,0.46,2.04,1.76$ and $2.44 \mathrm{~N} \cdot \mathrm{m}$, respectively). As the percentage of the $H$. tuberosus tuber flour increases, the water absorption capacity and dough formation time (TC1) decrease (fig. 2). A low resistance of dough to mixing was noted. A decrease in consistency (C2), showing a higher softening under the effect of temperature, reveals some negative qualitative changes in flour protein composition, i.e. changes or dilution of gluten content.

Dough stability times ranged from 5.05 to $8.97 \mathrm{~min}$, except for sample P5 (4.28 min,) (fig. 3). The lowest C3 was determined for pure wheat dough (P1) (table 5). The difference in $\mathrm{C} 3$ results between $\mathrm{P} 1$ and $\mathrm{P} 2$ samples was $0.04 \mathrm{~N} \bullet \mathrm{m}$; thus, the influence of flour mixture used for dough was insignificant; the same applies for C2. As mentioned above, the C4 parameter corresponds to the stability of the starch gel formed (fig. 4). This parameter was strongly influenced by the amount of $H$. tuberosus flour used in the flour mix. For P1 and P2, the difference between C4 parameter values $(1.35 \mathrm{~N} \cdot \mathrm{m}$ and, respectively, 1.38) is insignificant.

For the other samples, a gradual increase of the $\mathrm{C} 4$ parameter was noticed ( 1.8 for $\mathrm{P} 3$ and 1.94 for $\mathrm{P} 4$ ), except in the case of P5 where it decreased to 1.84.

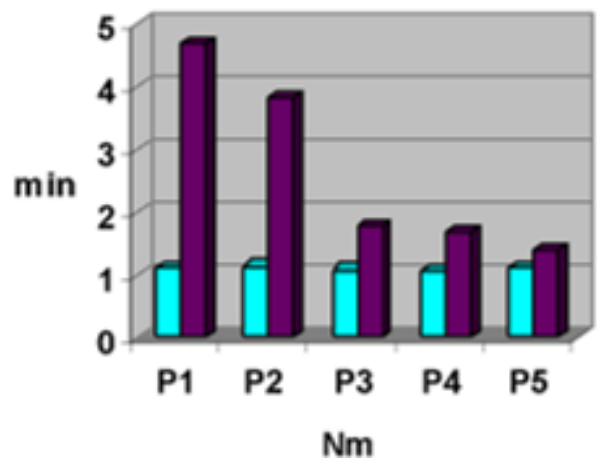

Fig. 2. Dough formation time

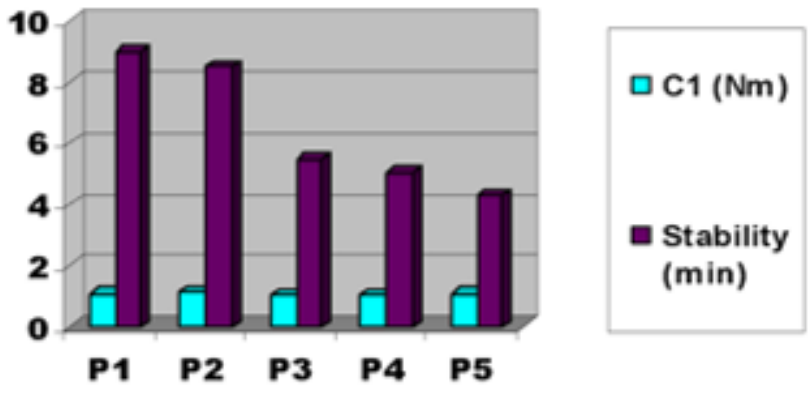

$\mathrm{Nm}$

Fig. 3. Dough stability times

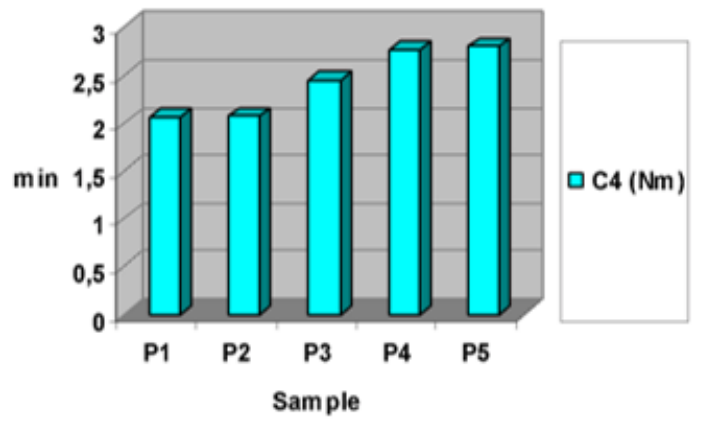

Fig. 4. Stability of starch gel

The retrogradation stage of starch (C5) in the analyzed wheatflour and wheat-tuber flour mixtures, demonstrated similar differences as the measurement for starch gel stability. Itcan be observed that differences in $\mathrm{C} 5$ between consecutive samples are not notable, but that the difference between $\mathrm{P} 1$ and $\mathrm{P} 5$ is considerable ( 2.05 and $2.80 \mathrm{~N} \bullet \mathrm{m}$, respectively).

\section{Bread properties}

The final moisture content of bread depends on the absorption of water during dough formation and water loss during baking. From table 8 , it is apparent that the addition of $H$. tuberosusflour has a significant effecton the moisture of the samples: P5 had the lowest moisture content (37.61) compared with the control (P1). The final bread volume depends on dough expansion during fermentation and baking, and on the ability of the matrix to stabilize the retained gas. The sample made from the mixture of wheat flour with $20 \% \mathrm{H}$. tuberosus, (P5), had a volume of 154 $\mathrm{cm}^{3}$, compared to the $\mathrm{P} 1$ sample volume which was 384 
Table 8

PHYSICOCHEMICAL RESULTS FOR THE EXPERIMENTAL BREAD SAMPLES

\begin{tabular}{|c|c|c|c|c|c|c|c|}
\hline Sample & $\begin{array}{c}\text { Mass } \\
\mathrm{kg}\end{array}$ & $\begin{array}{c}\text { Volume } \\
\mathrm{cm}^{3}\end{array}$ & $\begin{array}{c}\text { Porosity } \\
\%\end{array}$ & $\begin{array}{c}\text { Elasticity } \\
\%\end{array}$ & $\begin{array}{c}\text { Moisture } \\
\text { content \% }\end{array}$ & $\begin{array}{c}\text { Acidity, } \\
\text { degree }\end{array}$ \\
\hline P1 & 0.524 & 385 & 85.8 & 95 & $\begin{array}{c}\text { Pleasant taste and smell, specific } \\
\text { to white bread }\end{array}$ & 43.70 & 1.2 \\
\hline P2 & 0.540 & 226 & 72 & 92 & $\begin{array}{c}\text { Pleasant taste and smell specific to } \\
\text { bread with a high degree of } \\
\text { extraction }\end{array}$ & 42.31 & 1.6 \\
\hline P3 & 0.550 & 174 & 57.8 & 81 & $\begin{array}{c}\text { Smell of artichoke, sticky when } \\
\text { chewing }\end{array}$ & 41.18 & 1.9 \\
\hline P4 & 0.557 & 163 & 57.2 & 80 & $\begin{array}{c}\text { Strong smell of artichoke, sticky } \\
\text { when chewing }\end{array}$ & 40.47 & 2.0 \\
\hline P5 & 0.559 & 154 & 53.47 & 75 & $\begin{array}{c}\text { Strong smell of artichoke, sticky } \\
\text { when chewing }\end{array}$ & 37.61 & 2.2 \\
\hline
\end{tabular}

Table 9

SCORES OBTAINED FROM ORGANOLEPTIC EVALUATION OF BREAD SAMPLES USING THE BREAD SCORE

\begin{tabular}{|c|c|c|c|c|c|c|c|c|}
\hline Sample/ & Volume & $\begin{array}{c}\text { Marginal crack } \\
\text { height }\end{array}$ & $\begin{array}{c}\text { Skin } \\
\text { colour }\end{array}$ & $\begin{array}{c}\text { Colour } \\
\text { core }\end{array}$ & Porosity & Elasticity & Aroma & Total \\
\hline P1 & 23 & 7 & 6 & 10 & 17 & 17 & 12 & 92 \\
\hline P2 & 14 & 4 & 6 & 9 & 15 & 15 & 10 & 73 \\
\hline P3 & 11 & 3 & 5 & 5 & 6 & 7 & 4 & 41 \\
\hline P4 & 10 & 3 & 5 & 5 & 5 & 6 & 4 & 38 \\
\hline P5 & 9 & 3 & 4 & 4 & 4 & 4 & 4 & 32 \\
\hline
\end{tabular}

Explanations of types of flours in Table 1

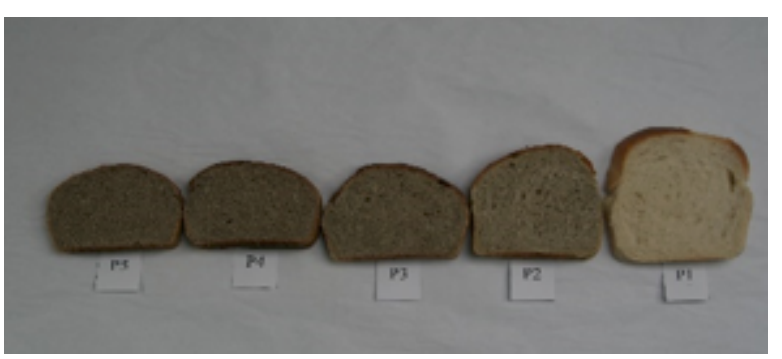

Fig. 5. Crumbs of bread enriched with different concentrations of Helianthus tuberosus

(P1, P2, P3, P4,P5)

$\mathrm{cm}^{3}$. This significant decrease is due to the dilution effect: soluble fibre affects gas retention as it interacts with the gluten network, but does not increase the gas production, resulting in a disrupted structure $[24,25]$.

These results seem to be correlated with the rheological data presented in table 7, as the specific volume decrease coincides with decreased consistency of the dough bread (C2). That means that the protein flour composition undergoes some negative qualitative changes, i.e. dilution of gluten content and changes in gluten structures. As it can be observed in table 8, there are major changes in all the parameters of bread samples with the highest concentration of $H$. tuberosusflour, when comparing them to P1 ( $100 \%$ wheat flour). The parameters of sample P2, the one with the lowest concentration of $H$. tuberosus flour, are far superior to the ones of the other flour mixtures.

In terms of acidity of the bread samples, the increase in percentage of $H$. tuberosus flour results in the increase of acidity up to 2.2 degrees, which is the typical value obtained for bread made from whole wheat.

According to the results obtained in porosity measurement experiments, it was noted that the high percentage of $H$. tuberosus flour did not allow gas formation and retention during baking, with visible consequences on bread porosity. However, the sample with the lowest content of $H$. tuberosusflour showed an acceptable porosity compared to that obtained from whole wheat bread. This is true for elasticity as well.

In figure 5 there are presented crumbs of bread enriched with different concentrations of $H$. tuberosus (P1, P2, P3,
P4, P5). Our research results are confirmed by various studies, with the difference that these studies used inulin powder extracted from $H$. tuberosus flour [26-31].

These studies indicated that wheat bread can be enriched with inulin up to $2.5 \mathrm{~g} / 100 \mathrm{~g}$ flour and still retain the quality attributes of conventional bread. Of note, in our work, the wheat flour mixture with $5 \% \mathrm{H}$. tuberosus contains about $3 \mathrm{~g}$ inulin per $100 \mathrm{~g}$ sample.

It can be seen in table 9 that wheat flour with $5 \% \mathrm{H}$. tuberosus flour is acceptable for making bread of similar organoleptic quality to whole-wheat flour bread. However, to improve the quality of the bread obtained from the flour mixture, it is necessary to choose a technology that improves both the formation and retention of gases and bread elasticity.

\section{Conclusions}

The chemical characterization performed in this study proved that erusalem artichoke ( $H$. tuberosus $L$.) flour is a valuable source of nutritional components, mainly inulin and minerals.

The main conclusion in our study with respect to rheological properties of dough made from wheat flour and $H$. tuberosus flour was that the P2 sample $(5 \mathrm{~g} \mathrm{H}$. tuberosus tuber flour added to $95 \mathrm{~g}$ wheat flour) retained suitable rheological parameters for obtaining bakery products of a good quality. After performing the baking test, it was observed that the best sensory and physicochemical values were obtained using an addition of $5 \% \mathrm{H}$. tuberosus tuber flour, and these were comparable to those of whole wheat bread.

This study provides useful information toward using $H$. tuberosus flour as source of functional ingredients in the bakery industry; in particular, this flour can be regarded as a valuable source of fibre (more than $3 \mathrm{gl}^{100 \mathrm{~g}^{-1}}$ ), according to Regulation 1924/2006.

Acknowledgements:This work was supported by a grant of the Roumanian Ministery of Research and Innovation, CCCDI-UEFISCDI, project no. PN-III-P1-1.2-PCCDI - 2017 - 0566/Ctr. 9 PCCDI/2018, within PNCDI III. 


\section{References}

1.POP, O.V., VAMANU, A., ERDELYI POP, A., VAMANU, E., NITA, S., Rev. Chim. (Bucharest), 67, no. 7, 2016, p. 1301

2.SOMDA Z. C., MCLAURINW. J., KAYS. S. J., J. of Plant Nutrition, 22, 1999, p. 1315;

3.TERZIC S., ATLAGIC J., MAKSIMOVIC I., ZEREMSKI T., MIROSLAV Z., MIKLIC V., BALALIC I., Scientia Horticulturae, 136, 2012, p. 135; 4.BACH V., LWT - Food Science and Technology, 54, 2013, p. 165; 5.RAMNANI P., GAUDIER E., BINGHAM VAN BRUGGEN P., TUOHYK. M., GIBSON G. R., British J ournal of Nutrition, 104, 2010, p. 233;

6.KAYS S. J., NOTTINGHAM S. F., Biology and chemistry of J erusalem artichoke: Helianthus tuberosus L., 2007, p. 53;

7.MADRIGAL L., SANGRONIS E., Arch. Latinoamericanos de Nutr., 57, no. 4, 2007, p. 387;

8.CAUNII, A., BUTU, M., RODINO, S., MOTOC, M., NEGREA, A., SAMFIRA, I., BUTNARIU, M., Rev.Chim. (Bucharest), 66, 2015, p. 472; 9.AJILA C.M., AALAMI M., LEELAVATHI K.,PRASADA RAO U. J. S., Innovative Food Science and Emerging Technologies, 11, 2010, p. 219;

10.TRINIDADT.P., MALLILLIN A.C., VALDEZD. H., LOYOLA A.S., ASKALIMERCADO F.C., CASTILLO J.C., ENCABO R.R., MASA D.B., MAGLAYA A. S.,CHUA M. T., Innovative Food Science and Emerging Technologies, 7, 2006, p. 309;

11.ROHIT K., SHRUTI P., ABUL K. N., VIDHU A., BIBHU P.P., Innovative Food Science and Emerging Technologies, 26, 2014, p. 490;

12.SINGH M., MOHAMED A., Food Science and Technology, 40, 2007, p. 353;

13.SUDHA M.L., BASKARAN L. K., Food Chem., 104, 2007, p. 686; 14.GHERGHINA E., ISRAEL-ROMING F., BALAN D., LUTA G., SIMION V., ZACHIA M., Scientific Bulletin. Series F. Biotechnologies, 19, 2015, p. 140;

15.TOMA R.B., ORR P.H., APPOLONIA B., DINTZIS F.R., TABEKHIA M. M., J. of Food Science, 44, 1979, p. 1403;
16.YU L.J., NGADI M.O., J of the Science of Food and Agriculture, 86, 2006, p. 544;

17.BAJIC B.Z., DAVIDOVIC D.N., VELICKOVIC D.T., MILOSAVLJEVIC N.P., DODIC S.N., DODIC J.M., Romanian Biotechnological Letters, 22, no.1, 2017, p. 12163;

18.NINESS K. R., J. of Nutrition, 129, 1999, p. 1402;

19.FRANCK A., British Journal of Nutrition, 87, 2002, p. 287;

20.PETKOVA D.N., PETKOVA N.T., DENEV P., Science Engineering and Technologies, 59, 2012, p. 339;

21.PETKOVA N.T., IVANOVA M., TEODOROVA M., VLASEVA R., DENEV P., Acta Scientifica Naturalis, 1, 2013, p. 91;

22.DUBAT A., Cereal Food World, 55, 2010, p. 150;

23.PAPOUSKOVA L., CAPOUCHOVA I., KOSTELANSKA M., SKERÍKOVA A., PROKINOVAE., HAJ SLOVA J ., Czech J ournal of Food Science, 29, 2011, p. 420;

24.MANDALA I., POLAKI A., YANNIOTIS S., J. of Food Engineering, 92, no. 2, 2009, p. 137;

25.MORRIS C., MORRIS G. A., Food Chemistry, 133, no. 2, 2012, p. 237;

26.PRAZNIK W., CIESLIK E., FILIPIAK F. A., Nahrung Food, 46, no.3, 2002, p.151;

27.WANG J. ROSELL C. M., BENEDITO DE BARBER C., Food Chem., 79, no. 2, 2002, p.221;

28.0'BRIEN C. M., MUELLER A., SCANNELL A. G. M., ARENDT E. K., Journal of Food Engineering, 56, no. 2-3, 2003, p. 265;

29.PERESSINI D., SENSIDONI A., J ournal of Cereal Science, 49, no. 2, 2009, p. 190.

30.POINOT P., ARVISENET G., GRUA-PRIOL J., FILLONNEAU C., LEBAIL A., PROST C. Food Chem., 119, no. 4, 2010, p. 1474;

31.HAGER. A. S., RYAN. L. A. M., SCHWAB. C.,GANZLE M. G.,O'DOHERTY J. V., ARENDT E. K., European Food Research and Technology, 232, no. 3, 2011, p. 405.

$\overline{\text { Manuscript received: } 11.07 .2018}$ 